\title{
PENGEMBANGAN DESAIN PEMBELAJARAN MATEMATIKA \\ DENGAN MEMANFAATKAN SISTEM SOSIAL MASYARAKAT
}

\author{
Usman Mulbar \\ FMIPA Universitas Negeri Makassar \\ email: u_mulbar@yahoo.com
}

\begin{abstract}
Abstrak: Penelitian ini bertujuan untuk menghasilkan desain pembelajaran matematika dengan memanfaatkan sistem sosial masyarakat untuk menumbuhkembangkan budaya kesatria dan integritas diri siswa SMP. Jenis penelitian ini adalah penelitian pengembangan yang produknya diharapkan dapat memfasilitasi proses belajar mengajar matematika. Sesuai dengan tahapan pengembangan, diperoleh hasiladalah sebagai berikut.Pertama, teori yang digunakann untuk mengembangkan desain pembelajaran adalah modifikasi model pengembangan sistem instruksional pembelajaran Thiagarajan. Fase-fase pengembangan yang dilalui adalah tahap: (1) pendefinisian (define); (2) perancangan (design); dan (3) dan pengembangan (develop). Kedua, desain pembelajaran matematika yang memanfaatkan sistem sosial masyarakat (rencana pelaksanaan pembelajaran, buku petunjuk guru, buku siswa, lembar kegiatan siswa, dan tes hasil belajar matematika) berkualitas baik adalah memenuhi kriteria validitas, praktisitas, dan efektivitas. Tes hasil belajar matematika dalam funginya sebagai instrumen penelitian memenuhi kriteria validitas, sensitivitas, dan reliabilitas. Validitas setiap item tes hasil belajar adalah sangat tinggi dan tinggi, sensititivitas setiap item tes memilikikepekaan, dan reliabilitas tes sangat tinggi.
\end{abstract}

Kata Kunci : desain pembelajaran matematika, sistem sosial masyarakat

\section{DEVELOPMENT OF MATHEMATICS INSTRUCTIONAL DESIGN BY UTILIZING THE COMMUNITY SOCIAL SISTEM}

\begin{abstract}
This study aims to produce designs that take advantage of mathematics learningsocial system to develop the practice of knight sand integrity in junior high schoolstudents. Therefore, this type of research isthe development of the productis expected to facilitate the teaching and learning of mathematics that lead to quality learning. Based on the stage of development reached, the obtained results, namely. First, the theory digunakann to develop mathematics instructional designis a modified model of learning instructional systems development Thiagarajan (1974). Phases of development to be taken, namely: (1) define; (2) design; and (3) develop. Second, mathematics instructional design that utilizes social system (lesson plan, guidethe teacher, student books, student activity sheet, and math achievement test) goodquality, which meets the criteria ofa valid, practical, and effective. Medium math achievement test in funginya as research instrumentsmeet the criteria ofvalidity, sensitivity, and reliability. The validity of each item achievement test is very high and high; sensititivitas each item test has sensitivity; and reliability of the test is very high.
\end{abstract}

Keywords: design study of mathematics, social system

\section{PENDAHULUAN}

Matematika merupakan ilmu universal yang mendasari perkembangan teknologi modern, mempunyai peran penting dalam berbagai disiplin ilmu dan memajukan daya pikir manusia. Perkembangan pesat di bidang teknologi informasi dan komunikasi dewasa ini dilandasi oleh perkembangan matematika di bidang teori bilangan, aljabar, analisis, teori peluang, dan matematika diskret. Kare- na itu, untuk menguasai dan memanfaatkan teknologi di masa depan diperlukan penguasaan matematika yang kuat sejak dini.

Berkaitan dengan penguasaan matematika sejak dini oleh siswa, dalam praktiknya pembelajaran matematika harus dikaitkan dengan pengalaman kehidupan nyata siswa, sehingga apa yang dipelajarinya menjadi bermakna dan dirasakan sangat bermanfaat dalam kehidupan sehari-hari. Se- 
bagian besar siswa mengalami kesulitan dalam pembelajaran matematika karena ketidakmampuannya dalam mengaplikasikan matematika ke dalam situasi kehidupan nyata. Hal lain yang menyebabkan matematika dirasakan sulit oleh siswa adalah proses pembelajarannya yang kurang bermakna. Guru dalam pembelajarannya di kelas tidakmengaitkanmateri yang diajarkan dengan skema yang dimiliki oleh siswa, dan siswa kurang diberi kesempatan untuk menemukan kembali dan mengkonstruksi sendiri ide-ide matematikanya. Mengaitkan pengalaman kehidupan nyata siswa dengan ide-ide matematika dalam pembelajaran dikelaspenting dilakukan agar pembelajaran menjadi bermakna. Heuvel-Panhuizen (2000) mengemukakan bahwa bila belajar matematika terpisah dari pengalaman mereka sehari-hari, siswa akan cepat lupa dan tidak dapat mengaplikasikan matematika. Dengan demikian, pembelajaran matematika dikelas sebaiknya ditekankanpadaketerkaitan antara konsep-konsep matematika dengan pengalaman siswa sehari-hari. Selain itu, siswa perlu dilatih menerapkan kembali konsep matematika yang telah dimilikinya pada kehidupan sehari-hari atau pada bidang lainnya.

Kecenderungan terjadinya pergeseran filosofi pembelajaran, yaitu dari paradigma behavioristik menuju konstruktivistik memaksa guru mengubah kebiasaan mengajarnya dan tidak sedikit yang merasa kebingungan dalam menerapkan paradigma baru yang diinginkan. Guru sangat sulit mengubah perilaku mengajar (teacher center) karena pergeseran filosofi tersebut berorientasi pada pembelajaran yang utuh (wholistic) yang memperhatikan perkembangan anak secara menyeluruh (comprehendship), meliputi pertumbuhan fisik, sosial, emosional, dan intelektual. Karena tujuan pembelajaran yang jauh berbeda, sedangkan guru melaksanakan pembelajaran dengan cara yang sama berdasarkan pengalaman sebelumnya sehinga dimungkinkan terjadinya mal fungsi paradigma.

Kenyataan menunjukkan bahwa sampai saat ini tingkat satuan pendidikan belum memiliki model pembelajaran (khususnya pembelajaran) yang lahir dari negeri ini berdasarkan kajianfilosofi sistem sosial masyarakat, nilai didikan leluhur atau hasil pemikiran para tokoh pen- didikan terdahulu. Model-model dengan paradigma baru pembelajaran dari dunia luar yang diadopsi dan diadaptasikan di sekolah tidak serta merta dapat diterapkan karena pada hakikatnya cara berpikir, persepsi, dan cara bertindak seseorang sangat dipengaruhi oleh budaya, lingkungan, dan orang lain di sekitarnya (Taylor, 1993). Oleh karena itu, dalam proses pembelajaran, berbagai hasil penelitian menunjukkan bahwa pembelajaran selama ini berpusat pada guru, kemudian siswa dijadikan sebagai objek sehingga siswa tidak mempunyai cukup waktu untuk mengkonstruksi pengetahuan yang dimiliki. Konsep dan prinsip yang diberikan dalam bentuk "jadi" dari guru ke siswa tanpa melalui proses abstraksi dan generalisasi.

Selain itu, ditinjau dari konsep pengembangan sistem pendidikan, penerapan model pembelajaran berbasis sistem sosial masyarakat sesuai denganide desentralisasi pendidikan yang sedang dikumandangkan saat ini. Desentralisasi merupakan salah satu upaya perbaikan efektivitas dan efisiensi pendidikan. Hal ini diharapkan dapat menumbuhkembangkan kemampuan daerah untuk meningkatkan potensinya secara mandiri melalui dua aspek, yaitu mendapat insentif daripenerapan model berbasis sistem sosial masyarakat. Oleh karena itu, pengembangan model pembelajaran matematika yang berorientasi pada pemahaman, pemecahan masalah, berbasis sistem sosial masyarakat sangat diperlukan guna memperkaya pengetahuan matematika siswa. Selain itu, juga untuk memampukan siswa menghadapi tantangan global, dan juga mendekatkan siswa pada lingkungan sosialnya.

Berdasarkan uraian yang dikemukakan di atas, maka permasalahan utama dalam penelitian ini adalah mengembangkan desain pembelajaran matematika yang memanfaatkan sistem sosial masyarakat. Dengan demikian, dalam penelitian ini perlu diantisipasi persiapan guru dalam melaksanakan pembelajaran matematika dengan menggunakan model pembelajaran matematika yang memanfaatkan sistem sosial.

\section{METODE}

Jenis penelitian adalah penelitian pengembangan (development research) yang dimaksud- 
kan untuk mengembangkan desain pembelajaran matematika yang memanfaatkan sistem sosial masyarakat. Produk yang dihasilkan adalah sekumpulan sumber belajar yang dipergunakan oleh guru dan siswa sebagai pedoman untuk mewujudkan proses pembelajaran matematika sehingga tujuan pembelajaran tercapai. Sumber belajar yang dimaksud adalah rencana pelaksanaan pembelajaran, buku guru, buku siswa, lembar kegiatan siswa, dan tes hasil belajar matematika.

Penelitian ini dibatasi pada siswa kelas VII SMP Negeri di Provinsi Sulawesi Selatan. Pemilihan subjek penelitian dilakukan dengan langkahlangkah, yaitu: (1) memilih 6 kabupaten/kota secara purposif; (2) memilihsatu SMP negeri di ibu kotakabupaten/kota secara random sebagai tempat pelaksanaan penelitian ini; (3) memilih dua kelas secara random dari sejumlah kelas yang ada untuk dijadikan subjek penelitian. Dengan demikian, siswa/guru matematika yang kelasnya terpilih merupakan subjek penelitian.

Pengembangan desain pembelajaran yang memanfaatkan sistem sosial masyarakat dalam penelitian ini berpedoman pada model pengembangan sistem instruksional pembelajaran yang dikembangkan oleh Thiagarajan, dkk. (1974) dengan beberapa modifikasi. Berdasarkan hasil modifikasi tersebut, tahap-tahap pengembangan pembelajaran yang memanfaatkan sistem sosial masyarakat adalah sebagai berikut. Tahap pendefinisian: kegiatan yang dilakukan pada tahap pendefinisian adalah mendeskripsikan hasil: analisis awal-akhir, analisis siswa, analisis materi, analisis tugas, dan spesifikasi tujuan pembelajaran. Tahap perancangan: kegiatan yang dilakukan pada tahap perancangan yaitu: penyusunan tes acuan patokan, pemilihan media, pemilihan format, disain awal. Tahap pengembangan: kegiatan yang dilakukan pada tahap ini, yaitu: validasipakar dan praktisi dan uji pengembangan.

Instrumen penelitian berupa lembar validasi, lembar observasi aktivitas siswa, lembar observasi kemampuan guru dalam mengelola pembelajaran matematika, angket respons siswa terhadap desain pembelajaran yang memanfaatkan sistem sosial masyarakat, dan tes hasil belajar matematika. Analisis data yang dilakukan meliputi (1) analisis data hasil validasi; (2) analisis data aktivitas siswa; (3) analisis data kemampuan guru dalam mengelola pembelajaran; (4) analisis data respons siswa terhadap desainpembelajaran; dan (5) analisis data tes hasil belajar matematika.

Analisis data tersebut adalah sebagai berikut. Berdasarkan data hasil penilaian kevalidan desain pembelajaran yang memanfaatkan sistem sosial masyarakat dari para pakar dan praktisi pendidikan matematika, kemudian ditentukan nilai rata-rata dari rata-rata nilai yang diberikan oleh masing-masing penilai. Selanjutnya, ditentukan nilai rata-rata total kevalidan desain pembelajaran yang memanfaatkan sistem sosial masyarakat dengan langkah-langkah sebagai berikut. Pertama, melakukan rekapitulasi data, yaitu skor hasil penilaian pakar dan praktisi pendidikan matematika ke dalam banyaknya aspek. Kedua, menentukan nilai rata-rata validasi (skor hasil penilaian pakar dan praktisi pendidikan matematika) untuk setiap aspek yang dinilai. Ketiga, menentukan nilai ratarata total (skor hasil penilaian pakar dan praktisi pendidikan matematika) untuk setiap aspek (Va).

Rata-rata nilai total (Va) tersebut, selanjutnya dirujuk pada interval pengkategorian kualitas desain yang diadaptasi dari Bloom, Madaus \& Hasting (1981) untuk menentukan tingkat validitas desain pembelajaran yang memanfaatkan sistem sosial masyarakat, yaitu:

$\mathrm{Va} \leq 1,5 \quad$ tidak valid.

$1,5<\mathrm{Va} \leq 2,5 \quad$ kurang valid.

$2,5<\mathrm{Va} \leq 3,5$ cukup valid.

$3,5<\mathrm{Va} \leq 4,5$ valid.

$4,5<\mathrm{Va} \leq 5 \quad$ sangat valid.

Keterangan: Va adalah nilai validitas desain pembelajaran

Kriteria kevalidan desain pembelajaran yang memanfaatkan sistem sosial masyarakat, apabila menurut penilaian pakar dan praktisi pendidikan matematika nilai Va berada pada kategori minimal valid. Apabila nilai Va pada kategori cukup valid, maka perlu dilakukan revisi berdasarkan masukan (koreksi) para pakar dan praktisi pendidikan matematika. Selanjutnya, dilakukan kembali validasi, demikian seterusnya sampai diperoleh desain pembelajaran yang memanfaatkan sistem sosial masyarakat yang ideal berdasarkan ukuran validitas isi dan validitas konstruk dengan kriteria minimal valid. 


\section{Analisis Data Aktivitas Siswa dalam Pembe- lajaran}

Analisis data aktivitas dilakukan dengan menentukan frekuensi dan persentase frekuensi yang dipergunakan oleh siswa dalam pembelajaran matematika realistik. Langkah-langkah analisis aktivitas siswa adalah sebagai berikut.

- Menentukan frekuensi hasil pengamatan aktivitas siswa untuk setiap indikator dalam satu kali pertemuan.

- Mencari persentase frekuensi setiap indikator, yaitu membagi besarnya frekuensi dengan jumlah frekuensi untuk semua indikator, kemudian dikalikan $100 \%$.

Waktu ideal aktivitas siswa untuk setiap indikator aktivitasnya dalam pembelajaran matematika realistik merujuk pada waktu yang telah ditetapkan pada rencana pelaksanaan pembelajaran (RPP).

Kriteria aktivitas siswa dikatakan efektif, apabila untuk setiap pertemuan yaitu rencana pelaksana pembelajaran (RPP) persentase frekuensi seluruh indikator aktivitas siswa dalam tugas (ontask) dan aktivitas siswa luar tugas (off-task) memenuhi batas kriteria waktu ideal yang telah ditetapkan dengan toleransi sebesar 5\%. Apabila kriteria aktivitas siswa belum memenuhi kriteria efektif, maka peneliti melakukan peninjauan dengan merevisi desain pembelajaran yang memanfaatkan sistem sosial masyarakat atau memberi masukan pada guru untuk memperhatikan aspek aktivitas siswa, khususnya pada indikator yang belum memenuhi kriteria waktu ideal yang telah ditetapkan. Selanjutnya, dilakukan uji coba ulang yang bertujuan untuk mendapatkan keefektifan desain pembelajaran yang memanfaatkan sistem sosial masyarakat berdasarkan indikator aktivitas siswa dalam mengelola pembelajaran.

\section{Analisis Data Kemampuan Guru dalam Me- ngelola Pembelajaran}

Analisis data kemampuan guru dalam mengelola pembelajaran matematika realistik dilakukan dengan mencari nilai kategori dari beberapa aspek penilaian yang diberikan berdasarkan rencana pelaksanaan pembelajaran. Langkah-langkah yang dipergunakan untuk menentukan kemampu- an guru dalam mengelola pembelajaran matematika realistik adalah sebagai berikut.

- Melakukan rekapitulasi data, yaitu skor hasil penilaian pengamat kedalam setiap aspek yang dinilai.

- Menentukannilai rata-rata, yaitu skor hasil penilaian pengamat untuk setiap aspek yang dinilai. Nilai tersebut merupakan nilai Kemampuan Guru (KG).

Nilai Kemampuan Guru (KG), selanjutnya dirujuk pada interval kriteria kualitas desain yang diadaptasi dari Bloom, Madaus \& Hasting (1981) untuk menentukan tingkat kemampuan guru dalam mengelola pembelajaran, yaitu:

- $4,5<\mathrm{KG} \leq 5$ sangat baik

- $3,5<\mathrm{KG} \leq 4,5$ baik

- $2,5<\mathrm{KG} \leq 3,5$ cukup baik

- $1,5<\mathrm{KG} \leq 2,5$ kurang baik

- $\mathrm{KG} \leq 1,5$ tidak baik

Keterangan: KG adalah nilai kemampuan guru

Kriteria kemampuan guru dalam mengelola pembelajaranmatematika realistik, apabila setiap aspek yang dinilai tingkat pencapaian nilai kemampuan guru memenuhi kriteria minimal cukup baik. Apabila nilai kemampuan guru dalam mengelola pembelajaran untuk setiap pertemuan rencana pelaksanaan pembelajaran (RPP) di bawah kriteria minimal cukup baik, maka peneliti melakukan peninjauan dengan merevisi desain pembelajaran yang memanfaatkan sistem sosial masyarakat atau memberi masukan pada guru untuk meningkatkan penguasaan dan keterampilan mengajarnya, khususnya pada bagian yang teramati belum memenuhi kriteria minimal cukup baik. Selanjutnya, dilakukan uji coba ulang yang bertujuan untuk mendapatkan kepraktisan desain pembelajaran yang memanfaatkan sistem sosial masyarakat berdasarkan indikator kemampuan guru dalam mengelola pembelajaran.

\section{Analisis Data Respons Siswa terhadap Desain}

Data hasil angket dianalisis dengan menentukan banyaknya siswa yang memberi jawaban bernilai respons positif dan negatif untuk setiap kategori yang ditanyakan dalam angket. Respons positif artinya siswa merespons dalam kategori senang, baru, berminat, jelas, dan tertarik untuk se- 
tiap aspek yang direspons terhadap desain pembelajaran matematika. Respons negatif berarti sebaliknya.

Kriteria untuk menyatakan bahwa respons siswa terhadap desain pembelajaran yang memanfaatkan sistem sosial masyarakat adalah positif, apabila lebih dari $80 \%$ siswa yang menyatakan seperti berikut. Pertama, senang terhadap desain pembelajaran yang memanfaatkan sistem sosial masyarakat. Kedua, desain pembelajaran yang memanfaatkan sistem sosial masyarakat merupakan hal baru. Ketiga, dapat memahami dengan jelas bahasa yang dipergunakan. Keempat, tertarik dengan penampilan (tulisan, ilustrasi/gambar dan letak gambar). Komentar siswa yang bersifat konstruktif dipergunakan sebagai bahan pertimbangan untuk melakukan revisi terhadap desain pembelajaran yang memanfaatkan sistem sosial masyarakat.

Apabila respons siswa terhadap desain pembelajaran yang memanfaatkan sistem sosial masyarakat belum memenuhi kriteria efektif, maka peneliti melakukan peninjauan dengan merevisi desain pembelajaran yang memanfaatkan sistem sosial masyarakat berdasarkan hasil respos siswa. Selanjutnya, dilakukan uji coba ulang yang bertujuan untuk mendapatkan keefektifan desain pembelajaran yang memanfaatkan sistem sosial masyarakat berdasarkan indikator respons siswa terhadap desainpembelajaran yang memanfaatkan sistem sosial masyarakat.

\section{Analisis Data Tes Hasil Belajar Matematika}

Analisis data tes hasil belajar matematika bertujuan untuk mendapatkan tes hasil belajar matematika yang berkualitas baik. Tes hasil belajar matematika dikatakan berkualitas baik, apabila memenuhi kriteria: (1) koefisien korelasi validitas tes memenuhi kriteria minimal tinggi; (2) sensitivitas setiap item tes lebih besar atau sama dengan 0,30; dan (3) koefisien reliabilitas tes memenuhi kriteria minimal tinggi. Karena itu, analisis tes hasil belajar matematika difokuskan pada analisis validitas, sesitivitas, dan reliabilitas.

\section{HASIL DAN PEMBAHASAN}

Salah satu produk dalam penelitian ini adalah menghasilkan desain pembelajaran matemati- ka yang memanfaatkan sistem sosial masyarakat yang berkualitas baik. Karena itu, melalui fasefase pengembangan desain pembelajaran, diperoleh prototipe desain pembelajaran matematika yang memanfaatkan sistem sosial masyarakat yang memenuhi keriteria valid, praktis, dan efektif. Hasil proses pengembangan desain pembelajaran adalah sebagai berikut.

Pertama, pengembangan desain pembelajaran matematika yang memanfaatkan sistem sosial masyarakat disesuaikan dengan prinsip dan karakteristik pembelajaran matematika. Berdasarkan hasil validasi, diperoleh bahwa: rencana pelaksanaan pembelajaran, buku petunjuk guru, buku siswa, lembar kegiatan siswa, dan tes hasil belajar matematika memenuhi kriteria valid. Hasil ini, sesuai dengan pendapat Neeven (2007) yang menyatakan bahwa suatu material pembelajaran dikatakan valid, apabila memenuhi: (1) material pembelajaran yang dikembangkan berdasarkan pada rasional teoretik yang kuat, dan (2) terdapat konsistensi secara internal antara komponen material pembelajaran yang dikembangkan. Berikut disajikan hasil belajar matematika setiap pelaksanaan uji coba. Persentase siswa yang memperoleh skor sangat baik untuk ujicoba II melebihi persentase siswa untuk ujicoba I. Untuk skor rendah, sedang, dan baik persentase siswa untuk uji coba I lebih baik dari persentase siswa pada uji coba II. Perbandingan keadaan skor keduanya divisualisasikan pada Gambar 1.

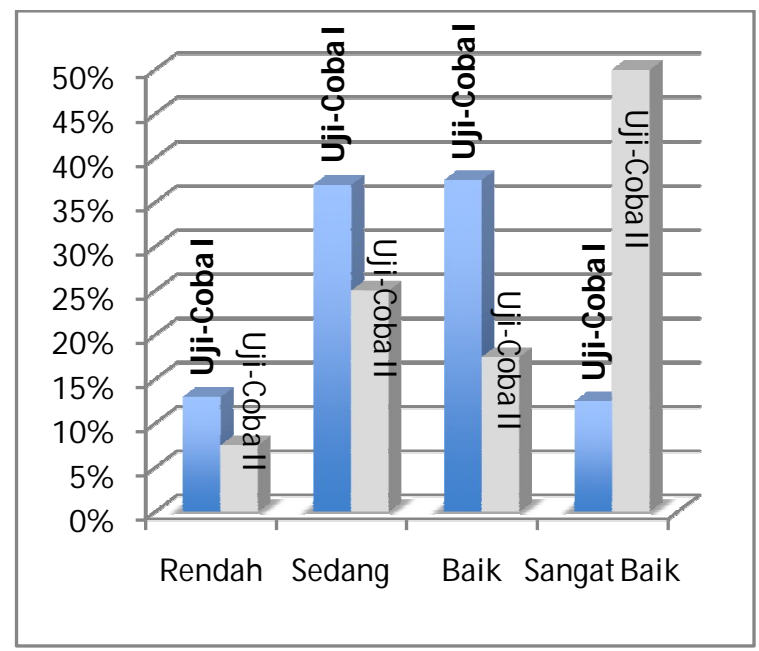

Gambar 1: Perbandingan Perolehan Skor Siswa dalam Uji Coba I dan II 
Kedua, Secara teoretis dan empiris desain pembelajaran matematika yang memanfaatkan sistem sosial masyarakat memenuhi kriteria praktis. Secara teoretis, hasil penilaian pakar dan praktisi pendidikan matematika menyatakan bahwa desainpembelajaran matematika yang memanfaatkan sistem sosial masyarakat dapat diterapkan di kelas. Secara empiris, hasil uji-coba memenuhi kriteria praktis ditinjau dari indikator kemampuan guru dalam mengelola pembelajaran.

Ketiga, keefektifan desain pembelajaran matematika yang memanfaatkan sistem sosial masyarakat ditentukan oleh tiga indikator, yaitu: aktivitas siswa dalam pembelajaran, ketuntasan belajar siswa secara klasikal, dan respons positif siswa terhadap proses pembelajaran. Pada pelaksanaan uji coba I, dari ketiga indikator, yaitu: indikator ketuntasan belajar siswa secara klasikal dan indikator respons siswa memenuhi kriteria keefektifan, sedangkan indikator aktivitas siswa dalam pembelajaran belum memenuhi kriteria. Pada pelaksanaan uji-coba II, indikator aktivitas siswa dalam pembelajaran matematika, ketuntasan belajar siswa secara klasikal, dan respons siswa terhadap desainpembelajaran matematika yang memanfaatkan sistem sosial masyarakat memenuhi kriteria keefektifan.

Keempat, fase-fase pembelajaran matematika yang memanfaatkan sistem sosial masya-rakat ditunjukkan pada Tabel 1.

Fase I: Apersepsi sistem sosial masyarakat sebagai pengantar sekaligus menyampaikan tujuan pembelajaran dan memotivasi siswa.

Tahap apersepsi sistem sosial masyarakat diawali dengan menginformasikan kompetensi dasar dan indikator yang akan dimiliki siswa setelah mempelajari materi yang akan diajarkan. Kemudian guru menumbuhkan persepsi positif dan motivasi belajar pada diri siswa melalui pemaparan keterkaitan pembelajaran dengan sistem sosial masyarak dan teori didikan leluhur. Selain itu, guru meyakinkan siswa bahwa jika siswa terlibat aktif dalam merekon- struksi konsep dan prinsip matematika, maka siswa lebih menguasai materi yang diajarkan. Hal ini disebabkan karena informasi baru berupa pengetahuan lebih bertahan lama di dalam ingatan siswa, dan pembelajaran lebih bermakna sebab konsep dan prinsip matematika dibangun berdasarkan pengalaman belajar dan pengalaman hidup yang dimiliki siswa. Selanjutnya, guru menjelaskan penerapan pola interaksi sosial masyarakat yang mengkondisikan keaktifan siswa dalam belajar (memecahkan masalah).

Fase II: Representasi pembelajaran melalui pola interaksi sosial masyarakat dan pengorganisasian siswa kedalam kelompok

Tahap representasi dan pemecahan masalah dengan pola interaksi sistem sosial masyarakat, guru meminta siswa duduk berkelompok. Pembentukan kelompok belajar menerapkan prinsip falsafah masyarakat. Guru memfasilitasi siswa dengan buku, dan lembar kegiatan siswa (LKS). Selanjutnya, guru mengajukan masalah yang ada pada buku siswa untuk diselesaikan tiap-tiap kelompok. Guru menanamkan nilainilai falsafah masyarakat agar para siswa saling berinteraksi secara sosio-kultural, memotivasi dan mengarahkan jalannya diskusi agar lebih efektif, memberi petunjuk dan membimbing kerja siswa, dan mendorong siswa bekerja sama.

Fase III: Persentase dan pengembangan hasil kerja

Pada tahapan ini, guru meminta salah satu kelompok mempresentasikan hasil kerjanya di depan kelas dan memberi kesempatan pada kelompok lain untuk memberi tanggapan berupa kritikan disertai alasan-alasan. Sesekali guru mengajukan pertanyaan menguji pemahaman/ penguasaan penyaji dan dapat ditanggapi oleh kelompok lain. Kriteria untuk memilih hasil diskusi kelompok yang akan dipresentasikan 
Tabel 1. Fase Pembelajaran Matematika dengan Pemanfaatan Sistem Sosial

Fase I: Apersepsi sistem sosial masyarakat sebagai pengantar sekaligusmenyampaikan tujuan pembelajaran dan memotivasi siswa.

\begin{tabular}{|c|c|}
\hline Kegiatan Guru & Kegiatan Siswa \\
\hline $\begin{array}{l}\text { - Menginformasikan kompetensi dasar \& } \\
\text { indikator } \\
\text { - Menciptakan persepsi positif dalam diri siswa } \\
\text { terhadap sistem sosial masyarakat (budaya) dan } \\
\text { memandang matematika sebagai hasil konstruksi } \\
\text { sosial. } \\
\text { - Menjelaskan pola interaksi sosial masyarakat } \\
\text { dalam belajar (memecahkan masalah). } \\
\text { - Memberikan motivasi belajar pada siswa melalui } \\
\text { penanaman nilai-nilai didikan sosial masyarakat }\end{array}$ & $\begin{array}{l}\text { - Mendengar penjelasan guru. } \\
\text { - Mendengar penjelasan guru dan bertanya bila belum jelas } \\
\text { tentang sistem sosial masyarakat dan membayangkan masalah } \\
\text { matematika yang bersumber dari fakta dan lingkungan } \\
\text { masyarakat } \\
\text { - Mendengar penjelasan guru tentang sistem sosial masyarakat } \\
\text { dalam memecahkan masalah, seperti: pantang menyerah, jujur, } \\
\text { berprinsip, konsisten dan sebagainya. } \\
\text { - Mendengar penjelasan guru tentang nilai-nilai didikan sosial } \\
\text { masyarakat (pantang menyerah, jujur, berprinsip, konsisten, dsb) }\end{array}$ \\
\hline
\end{tabular}

Fase II:Representasi pembelajaran melalui pola interaksi sosial masyarakat dan pengorganisasiansiswa kedalam kelompok

- Membentukan kelompok

- Membentuk kelompok

- Mengajukan masalah yang bersumber dari fakta dan lingkungan masyarakat

- Mendorong siswa bekerjasama menyelesaikan tugas-tugas

- Membimbing, mendorong/mengarahkan siswa memecahkan masalah dan mengerjakan LKS

- Memberikan scaffolding pada kelompok atau individu yang mengalami kesulitan

Fase III: Presentase dan pengembangan hasil kerja.

- Memberi kesempatan pada kelompok mempresentasikan hasil pemecahan masalah di depan kelas

- Membimbing siswa menyajikan hasil kerja

- Memberi kesempatan kelompok lain mengkritisi/ menanggapi hasil kerja kelompok penyaji

- Mengontrol jalannya diskusi agar pembelajaran berjalan dengan efektif

- Mendorong keterbukaan, proses-proses demokrasi dalam bedisikusi

- Bersama kelompok berdiskusi tentang penyelesaian masalah yang diberikan

- Bekerjasama dalam menyelesaikan masalah yang diberikan

- Menyelesikan masalah dan menuliskan penyelesaiannya di LKS

- Menyelesikan masalah, namun bila ada yang belum jelas menanyakan pada guru (baik kelompok maupun individu) dan memperhatikan penjelasan guru

- Salah seorang anggota kelompok mempersentasikan hasil penyelesaiannya d kelas

- Menyajikan hasil kinerja kelompok sambil mendengan penjelasan guru

- Memperhatikan, berdiskusi, dan menjawab/memberi tanggapan tentang hasil penyelesaian masalah

- Menguji pemahaman siswa

- Menjawab beberapa pertanyaan guru/siswa

Fase IV: Penemuan objek matematika disertai pengembangan skemata baru.

- Mengarahkan siswa membangun konsep dan prinsip secara ilmiah

- Mengkaji ulang hasil pemecahan masalah yang telah diselesaikan baik secara individu maupun secara berkelompok

- Menguji pemahaman siswa atas konsep yang ditemukan melalui pengajuan contoh dan bukan contoh

- Membantu siswa mendefinisikan dan mengorganisasikan tugas-tugas belajar yang berkaitan dengan masalah

- Memberi kesempatan melakukan konektivitas konsep dan prinsip dalam mengerjakan soal tantangan

- Menyelesaikan soal-soal yang diberikan baik secara individu maupun secara berkelompok

- Memberikan scaffolding

Fase V: Refleksi hasil pembelajaran disertai penghargaan.

- Membantu siswa mengkaji ulang hasil pemecahan masalah

- Memotivasi siswa untuk terlibat dalam pemecahan masalah yang selektif

- Mengevaluasi materi akademik: membuat peta konsep atau peta materi atau pemberian kuis

- Memberi tugas PR

- Baik secara berkelompok atau secara individu melakukan pengorganisasian tuga-tugas belajar yang telah ia lakukan

- Baik secara berkelompok atau secara individu menyelesikan soal-soal dan meminta bantuan dari guru bila ada yang belum jelas
- Menjawab pertanyaan guru dan menjawab pertanyaan guru dan bertanya bila ada permasalahan belum ia pahami

- Membuat catatan tentang hal-hal yang dianggap penting sebagai rangkuman hasil pembelajaran

- Menjawab pertanyaan guru secara lisan dan menyelesaikan soalsoal yang diberikan

- Mencatat tuga-tugas yang diberikan baik secara individu atau kelompok 
antara lain: jawaban kelompok berbeda dengan jawaban dari kelompok lain, ada ide penting dalam hasil diskusi kelompok yang perlu mendapat perhatian khusus. Dengan demikian, kelompok penyaji bisa lebih darisatu. Selama presentasi hasil kerja, guru mendorong terjadinya diskusi kelas dan mendorong siswa mengajukan ide-ide secara terbuka dengan menanamkan nilai-nilai sosial masyarakat

Tujuan tahapan ini adalah untuk mengetahui keefektifan hasil diskusi dan hasil kerja kelompok pada tahapan sebelumnya. Dalam penyajiannya, kelompok penyaji akan diuji oleh kelompok lain danguru tentang penguasaan dan pemahaman mereka atas pemecahan masalah yang dilakukan. Dengan cara tersebut di-mungkinkan tiap-tiap kelompok mendapatkan pemikiran-pemikiran baru dari kelompok lain atau alternatif jawaban lain yang berbeda. Selain itu, tujuan tahapan ini adalah melatih siswa terampil menyajikan hasil kerjanya melalui penyampaian ide-ide di depan umum (teman satu kelas). Keterampilan mengkomunikasikan ide-ide tersebut adalah salah satu kompetensi yang dituntut dalam pembelajaran model sismat untuk memampukan siswa berinteraksi/berkolaborasi dengan orang lain.

Fase IV: Penemuan objek matematika disertai pengembangan skemata baru

Objek-objek matematika berupa model (contoh konsep) yang diperoleh dari proses dan hasil pemecahan masalah untuk dijadikan bahan inspirasi dan abstraksi konsep melalui penemuan ciri-ciri konsep oleh siswa dan mengkonstruksi konsep secara ilmiah. Setelah konsep ditemukan, guru melakukan teorema pengontrasan melalui pengajuan contoh dan bukan contoh. Dengan mengajukan sebuah objek, guru meminta siswa memberi alasan, apakah objek itu termasuk contoh atau bukan contoh konsep.

Guru memberi kesempatan bertanya atas hal-hal yang kurang dipahami. Sesekali guru menguji pemahaman siswa atas konsep dan prinsip yang ditemukan, serta melengkapi hasil pemikiran siswa dengan memberikan contoh dan bukan contoh konsep. Selanjutnya, siswa diberi kesempatan mengerjakan soal-soal tantangan untuk menunjukkan kebergunaan konsep dan prinsip matematika yang ditemukan.

Fase V: Refleksi hasil pembelajaran disertai penghargaan.

Pada tahapan ini, guru membantu siswa secara individu mengkaji ulang hasil pemecahan masalah, menguji pemahaman siswa dalam proses penemuan konsep dan prinsip. Selanjutnya, guru melakukan evaluasi materi akademik. Misalnya, meminta siswa mengerjakan kuis, membuat peta konsep atau materi.

Ada sejumlah penelitian yang terkait dengan pembelajaran matematika di sekolah. Misalnya, penelitian pengembangan bahan matematika untuk level SMP yang dikembangkan oleh Murwaningsih, dkk. (2014), yaitu tentang pengembangan perangkat pembelajaran matematika realistik, dengan prosedur yang tidak berbeda. Hasilnya adalah buku perangkat pembelajaran yang dapat dipergunakan di sekolah. Sebelumnya, pembelajaran dengan pendekatan matematika realistik juga pernah dilakukan oleh Syahputra (2013), yaitu berikaitan dengan kemampuan spasial. Hasil penelitian disimpulkan bahwa siswa dibelajarkan dengan pendekatan matematika realistik lebih baik daripada kemampuan spasial siswa yang dibelajarkan dengan pendekatan konvensional. Jadi, pengembangan perangkat pembelajaran matematika realistik ini cukup baik. Di pihak lain, Redhana (2014) melakukan penelitian lain yang meneliti perbedaan hasil belajar sebagai akibat penerapan model pembelajaran tertentu yaitu yang meneliti efek penerapan pembelajaran model seminar Socrates dan model pembelajaran langsung. Hasilnya memperlihatkan bahwa siswa yang belajar dengan model pembelajaran seminar Socrates menunjukkan hasil lebih tinggi daripada siswa yang belajar dengan model pembelajaran langsung.

Berikut disajikan prototife desain pembelajaran matematika yang memanfaatkan sistem sosial masyarakat. 

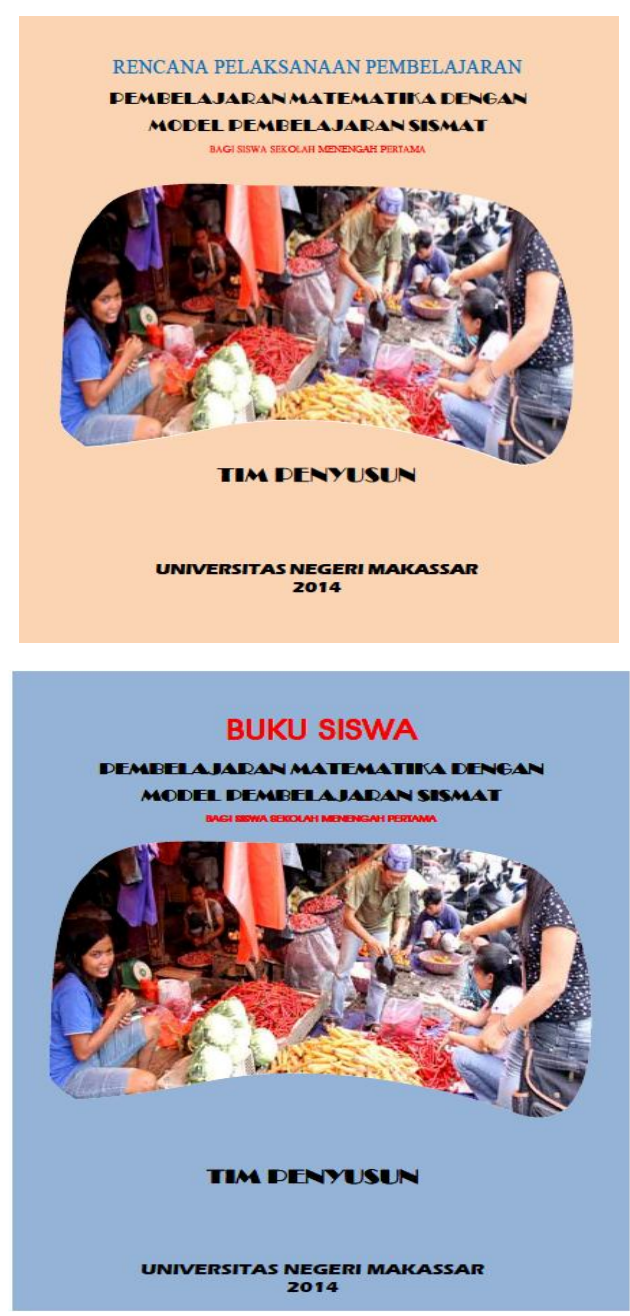

\section{PENUTUP}

Produk penelitian ini adalah desain pembelajaran matematika yang memanfaatkan sistem sosial masyarakat. Melalui fase-fase pengembangan desain pembelajaran, diperoleh simpulan dan saran dalam penelitian ini adalah sebagai berikut.

\section{Simpulan}

Desain pembelajaran matematika yang memanfaatkan sistem sosial masyarakat diperoleh melalui proses pengembangan yang telah memenuhi kriteria valid, praktis, dan efektif. Desain pembelajaran ini merupakan hasil pengembangan yang mencakup komponen-komponen: rencana pelaksanaan pembelajaran, buku petunjuk guru, buku siswa, lembar kegiatan siswa, dan tes hasil belajar matematikayang memenuhi kriteria valid, praktis, dan efektif. Tes hasil belajar matematika dalam funginya sebagai in-
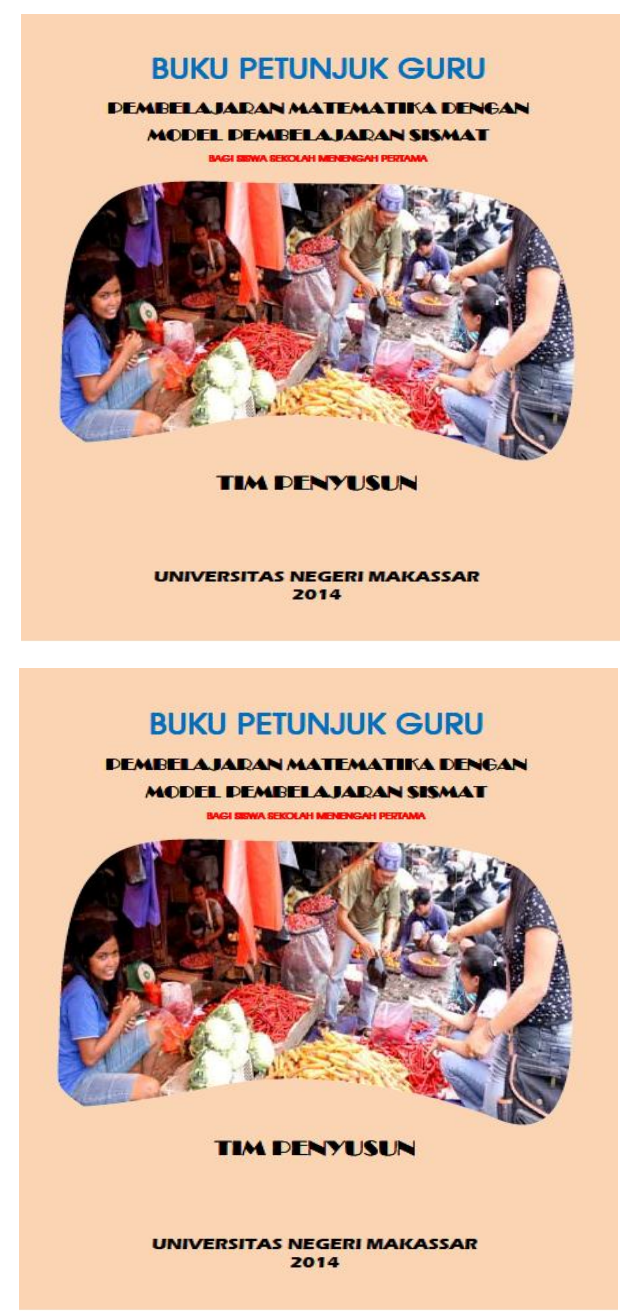

strumen penelitian memenuhi kriteria validitas, sesitivitas, dan reliabilitas. Validitas setiap item tes hasil belajar matematika adalah sangat tinggi dan tinggi; sensititivitas setiap item tes hasil belajar matematika memiliki kepekaan; dan reliabilitas tes hasil belajar matematika adalah sangat tinggi.

\section{Saran}

Berdasarkan simpulan penelitian, dapat diberi beberapa saran kepada praktisi yang berminat untuk menerapkan desain pembelajaran matematika yang memanfaatkan sistem sosial masyarakat dalam pelaksanaan pembelajaran di kelas adalah sebagai berikut.

Pertama, desain pembelajaran matematika yang memanfaatkan sistem sosial masyarakat yang dihasilkan, belum dimplementasikan secara luas di sekolah-sekolah, khususnya di Sekolah Menengah Pertama (SMP). Karena itu, untuk mengetahui keefektifan 
desain pembelajaran matematika yang memanfaatkan sistem sosial masyarakat, disarankan kepada para guru dan peneliti lainnya untuk mengimplementasikan desain pembelajaran matematika yang memanfaatkan sistem sosial masyarakat pada ruang lingkup yang lebih luas di sekolah-sekolah, khususnya di SMP. Dengan demikian, hasil-hasil penelitian yang terkait dengan desain pembelajaran matematika yang memanfaatkan sistem sosial masyarakat dapat dijadikan referensi untuk mengembangkan desain pembelajaran lainnya dan tetap melibatkan metakognisi siswa.

Kedua, bagi guru matematika yang berkeinginan menerapkan desain pembelajaran matematikayang memanfaatkan sistem sosial masyarakat pada materi yang lain, dapat mengembangkan sendiri desain pembelajaran yang diperlukan dengan memperhatikan karakteristik dari materi pelajaran yang akan dikembangkan.

Ketiga, guru yang berupaya untuk meningkatkan penguasaan konsep dan kemampuan siswa menyelesaikan masalah, serta meningkatkan minat siswa dalam belajar matematika, penerapan desain pembelajaran matematika yang memanfaatkan sistem sosial masyarakat dapat dijadikan salah satu alternatif jawaban permasalahan tersebut.

\section{UCAPAN TERIMA KASIH}

Segala puji dan syukur penulis panjatkan kepada Allah SWT karena dengan kehendak dan izin-Nya serta rahmat dan hidayah-Nya, penelitian ini dapat diselesaikan. Berkenaan dengan itu, sepantasnya penulis menyampaikan penghargaan dan ucapan terima kasih kepada: (1) Direktur DP2M Dikti yang telah meberikan dana melalui penelitian Hibah Bersaing multiyears; (2) Pimpinan UNM Makassar atas kesempatan yang diberikan kepada kami untuk melaksanakan penelitian ini; dan (3) pengelola Jurnal Ilmiah Cakrawala Pendidikan Universitas Negeri Yogyakarta yang telah menerbitkan hasil penelitian ini.

\section{DAFTAR PUSTAKA}

Bloom, Madaus \& Hasting. 1981. Methods Grading in Summative Evaluation. New York: McGraw-Hill.

Murwaningsih, Utami, Erika Laras Astutiningtyas, \& Nuryani Tri Rahayu. 2014. "Implementasi Pengembangan Perangkat Pembelajaran Matematika Realistik di Sekolah Menengah Pertama". Cakrawala Pendidikan. Th. XXXIII, No.3, hlm. 463473.

Nieveen, Nienke., 2007. "An Introduction to Educational Design Research". Proceedings of the Seminar Conducted at the East China Normal University, Shanghai (PR China), November 23-26, 2007.

Redhana, I Wayan. 2014. "Pengaruh Model Pembelajaran Seminar Socrates terhadap Hasil Belajar Siswa”. Cakrawala Pendidikan. Th. XXXIII, No.1, hlm. 27-38.

Syahputra, Edi. 2013. "Peningkatan KemampuanSpasial Siswa melalui Penerapan Pembelajaran Matematika Realistik". Cakrawala Pendidikan. Th. XXXII, No.3, hlm. 353-364.

Taylor, Lyn. 1993. "Vygotskyan Scientific Concepts: Implications for Mathematics Education". Focus on Learning Problems In Mathematics. Vol. 15, 2-3.

Thiagarajan, S., Semmel, D.S., dan Semmel, M.I. 1974. Intructional Development for Training Teachers of Exceptional Children. Minnesota: University of Minnesota. 